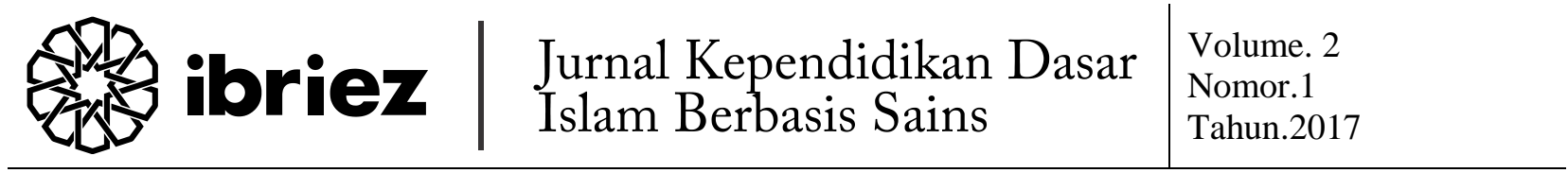

\section{Eksistensi Pendidikan Kewarganegaraan di Perguruan Tinggi Dalam Memperkokoh karakter Bangsa Indonesia}

\author{
Farida Sekti Pahlevi \\ Dosen IAIN Ponorogo \\ faridapo55@gmail.com
}

\begin{abstract}
Abstrak
Pendidikan kewarganegaraan merupakan bagian utuh dari sistem pendidikan nasional.Oleh karena itu proses pendidikan kewarganegaraan perlu diwujukan dalam kurikulum dan pembelajaran pada semua jalur dan jenjang pendidikan. Fungsi dan peran dalam rangka pencapaian tujuan pendidikan nasional, pendidikan kewarganegaraan dirancang, dikembangkan, dilaksanakan, dan dievaluasi dalam konteks pengejawantahan tujuan pendidikan nasional. Ketiga hal tersebut merupakan landasan dan kerangka pikir untuk memahami serta menerapkan Pendidikan kewarganegaraan.Pendidikan kewarganegaraan merupakan kebutuhan yang sangat mendesak bagi bangsa dalam membangun kehidupan yang aman, nyaman, damai, sejahtera. Dalam membangun demokrasi berkeadaban dibutuhkan generasi bangsa yang cerdas, berkarakter kokoh. Ada beberapa alasan mengapa pendidikan kewarganegaraan sangat dibutuhkan, pertama, meningkatnya gejala dan kecenderungan tidak political literacy atau tidak "melek" politik dan tidak mengetahui cara kerja demokrasidan lembaga-lembaganya; kedua, meningkatnya politichal apatishm yang ditunjukkan dengan sedikitnya keterlibatan warga negara dalam proses-proses politik. Pembentukan warga negara yang cerdas secara intelektual, emosional, sosial, serta spiritual benar-benar merupakan tuntutan dan keniscayaan. Disinilah eksistensi pendidikan kewarganegaraan menjadi sarana yang sangat pentingbagi negara-negara demokrasi termasuk negara Indonesia agar dapat melahirkan generasi bangsa yang mengetahui nilai-nilai kebangsaan berdasarkan Pancasila dan memiliki keterampilan yang diperlukan dalam mentransformasikan, mengaktualisasikan, dan melestarikan segala hal yang dimiliki oleh NKRI.
\end{abstract}

Kata kunci: Eksistensi, Pendidikan Kewarganegaraan, karakter, Kokoh 


\begin{abstract}
:
Citizenship education is an integral part of the national education system.Therefore the civic education process needs to be addressed in the curriculum and learning on all paths and levels of education.Functions and roles in the context of achieving national educational objectives, civic education are designed, developed, implemented and evaluated in the context of the embodiment of national education objectives. They are the foundation and frame of mind for understanding and applying civic education.Citizenship education is a very urgent need for the nation in building a safe, comfortable, peaceful, prosperous life.In building a civilized democracy, it needs a generation of intelligent, strong-minded nation.There are several reasons why civic education is urgently needed, firstly, the rise in political literacy and not political literacy and not knowing the workings of democracy and its institutions;Secondly, the increased politichal apathism is demonstrated by the lack of citizen involvement in political processes.The intellectual, emotional, social, and spiritual formation of intelligent citizens is really a demand and necessity. This is where the existence of civic education becomes a very important tool for democratic countries including the state of Indonesia in order to give birth to a generation of nations who know the values of nationality based on Pancasila and have the necessary skills in transforming, actualizing and preserving everything that is owned by NKRI.
\end{abstract}

Keywords: Existence, Civic Education, Character, Solid

\section{PENDAHULUAN}

Pendidikan merupakan unsur terpenting suatu negara yang harus diperhatikan. Sistem pendidikan yang tepat maka akan membawa kemajuan bagi suatu negara dan begitupun sebaliknya disaat sistem pendidikan tidak tepat maka kemajuan negara di pertaruhkan. Kehidupan berbangsa dan bernegara Indonesia mengalami suatu perubahan dan perkembangan yang sangat besar terutama berkaitan dengan kondisi pendidikan kewarganegaraan yang tumbuh dalam diri bangsa Indonesia. Di era reformasi dan globalisasi, kondisi Pancasila seakan-akan "hilang dari jiwa dan raga sebagian besar generasi bangsa" dan bahkan hanya cenderung dijadikan slogan semata. Padahal Pendidikan Kewarganegaraan sesungguhnya tidak hanya dibutuhkan bangsa Indonesia semata tetapi juga mengandung makna dijadikan pengetahuan dan pijakan dalam berfikir dan bertindak bangsa Indonesia.

Fenomena maraknya KKN, tingginya angka pengangguran, transaksi jual beli gelar dan rendahnya mutu pendidikan, serta diperparah lagi dengan adanya tawuran, demontrasi anarkis, penyalahgunaan narkoba, perdagangan manusia, kejahatan seksual, kriminalitas meningkat, budaya lulusan sekolah yang memilukan sangat mudah ditemui dikehidupan bangsa Indonesia saat ini. Murid-murid sekolah dari tingkat SD sampai dengan perguruan tinggi sudah mengenal, bahkan mempraktikan beberapa hal tersebut. Memang tidak semua para pelajar kita bertindak seperti itu tetapi semakin lama fenomena ini. menjadi. Murid-murid SMP, SMA, bahkan mahasiswa sering kedapatan membawa 
senjatatajam mulai dari samurai, golok sampai ikat pinggang bergerigi di dalam tas pada saatmereka masih menggenakan seragam sekolah, dan ini sungguh memperihatinkan.

Eksistensi sebuah bangsa dapat diukur dari sejauh mana bangsa itu mampu memberikan kontribusi yang nyata bagi kemajuan peradaban dunia. Peradaban yang maju adalah produk dari bangsa yang maju, yang didalamnya terdapat masyarakat yang memiliki pola pikir dan perilaku yang maju pula. Setiap bangsa pasti memiliki adat istiadat, kebudayaan, bahasa, serta sistem kepercayaan yang berbeda-beda antar satu dan lainnya. Meskipun berbeda, nilainilai dasar yang dijadikan pedoman bagi setiap bangsa pada umumnya adalah nilainilai yang hampir sama, yaitu sebuah nilai luhur yang berimplikasi positif bagi kemajuan ummat manusia. Tak ada satupun bangsa didunia ini yang berpedoman pada sebuah nilai yang bertentangan dengan nilai-nilai kemanusian (nilai Universal). ${ }^{1}$

Pendidikan Kewarganegaraan (civic education) tidak bisa lepas dari konteks ikhtiar kalangan perguruan tinggi untuk menemukan format baru pendidikan demokrasi di Indonesia sekaligus mengantisipasi tuntutan global. Globalisasi ditandai oleh kuatnya pengaruh lembagalembaga kemasyarakatan internasional, negara- negara maju yang ikut mengatur perpolitikan, perekonomian, sosial budaya, dan pertahanan keamanan global.

\footnotetext{
${ }^{1}$ Farida Sekti Pahlevi, "REAKTUALISASI PANCASILA SEBAGAI UPAYA PENINGKATAN KUALITAS PENDIDIKAN MORAL BANGSA INDONESIA," Al-Adabiya: Jurnal Kebudayaan Dan Keagamaan 9, no. 1 (2014): 21-44.
}

Isu-isu global seperti demokrasi, hak asasi manusia dan lingkungan hidup turut pula mempengaruhi keadaan nasional. Globalisasi juga ditandai dengan pesatnya perkembangan ilmu pengetahuan dan teknologi, khususnya di bidang informasi, komunikasi, dan transportasi membuat dunia menjadi transparan seolah-olah menjadi sebuah kampung tanpa mengenal batas negara. Kondisi ini akan mempengaruhi pola pikir, pola sikap, dan tindakan masyarakat Indonesia. ${ }^{2}$

Pendidikan kewarganegaraan sebenarnya dilakukan dan dikembangkan di seluruh dunia, meskipun dengan berbagai macam istilah atau nama. Mata Kuliah tersebut sering disebut sebagai civic education, citizenship education dan bahkan ada yang menyebut sebagai democracy education. Mata kuliah ini memiliki peranan yang strategis dalam mempersiapkan warga negara yang cerdas, bertanggung jawab dan berkeadaban. Berdasarkan keberhasilan pengembangan dan pemeliharaan pemerintahan demokrasi .

Berdasarkan Undang Undang Republik Indonesia Nomor 20 Tahun 2003, tentang Sistem Pendidikan Nasional, serta Surat Keputusan Direktur Jenderal Pendidikan Tinggi Departemen Pendidikan Nasional Nomor 43/DIKTI/Kep/2006, tentang ramburambu pelaksanaan kelompok mata kuliah pengembangan kepribadian di perguruan tinggi terdiri atas mata kuliah Pendidikan Agama, Pendidikan Kewarganegaraan dan

\footnotetext{
${ }^{2}$ Karuna Darani, accessed April 2, 2017, http://www.kompasiana.com/karunadarani/pentingnya -pendidikan kewarganegaraan-di-perguruan-tinggipada-era globalisasi_54f76d8aa33311d6338b495d.
} 
Bahasa Indonesia. Berdasarkan ketentuan tersebut maka kelompok mata kuliah pengembangan kepribadian tersebut wajib diberikan di semua fakultas dan jurusan di seluruh perguruan tinggi di Indonesia. ${ }^{3}$ Selanjutnya dalam Pasal 56 Undang-Undang Nomor 12 Tahun 2012 Tentang Pendidikan Tinggi kembali dikukuhkan wajib adanya mata kuliah Pancasila dan kewarganegaraan, yang masing-masing merupakan entitas utuh psikopedagogis/andragogis. ${ }^{4}$

Sebuah bangsa bisa disebut sebagai bangsa yang maju dan kuat apabila nilainilai dasar yang menjadi pedomannya benar-benar termanifestasi dalam perilaku sehari-hari. Sehingga dalam kehidupan berbangsa tidak ada lagi perilaku penyimpangan, penyelewengan, penjajahan, diskriminasi dan perilakuperilaku negatif lainnya. Bangsa Indonesia saat ini seolah sedang berada pada posisi yang rentan terhadap berbagai pengaruh dan masalah.

Berbagai permasalahan terjadi di bangsa ini dan bermacam-macam wujudnya, bisa masuk ke aspek apa saja termasuk aspek pendidikan. Hampir disetiap sektor kehidupan tidak luput dari permasalahan yang tidak kunjung terselesaikan. Perguruan tinggi merupakan wadah menempa generasi bangsa untuk menjadi tonggak utama kemajuan bangsa Indonesia. Mental generasi bangsa yang kokoh, tidak mudah terpengaruh oleh faham radikal atau rasis,

\footnotetext{
${ }^{3}$ Ahmad Kaelan \& Zubaidi, "Pendidikan Kewarganegaraan Untuk Perguruan Tinggi," Yogyakarta: Paradigma, 2007.

4 "Pedoman Matakuliah Pendidikan Kewarganegaraan (Pkn) Sebagai Mata Kuliah Wajib Umum (MKWU)" (DIKTI-MKWU, 2014).
}

nasionalisme dan patriotisme yang tidak mudah goyah sangat diharapkan oleh negara Indonesia.

\section{PENDIDIKAN KARAKTER}

Pendidikan Kewarganegaraan dibentuk oleh dua kata, ialah kata "pendidikan" dan kata "kewarganegaraan". Untuk mengerti istilah pendidikan, dapat melihat Kamus Umum Bahasa Indonesia (KUBI) atau secara lengkap lihat definisi pendidikan dalam Undang-Undang Republik Indonesia Nomor 20 Tahun 2003 tentang Sistem Pendidikan Nasional Pasal 1 Ayat (1), yang berbunyi;

Pendidikan adalah usaha sadar dan terencana untuk mewujudkan suasana belajar dan proses pembelajaran agar peserta didik secara aktif mengembangkan potensi dirinya untuk memiliki kekuatan spiritual keagamaan, pengendalian diri, kepribadian, kecerdasan, akhlak mulia, serta keterampilan yang diperlukan dirinya, masyarakat, bangsa dan negara. ${ }^{5}$

Batasan tentang pendidikan, Pendidikan seperti sifat sasarannya yaitu manusia, mengandung banyak aspek dan sifatnya sangat kompleks. Karena sifatnya yang kompleks itu maka tidak sebuah batasanpun yang cukup memadai untuk menjelaskan arti pendidikan secara lengkap. Batasan tentang pendidikan yang dibuat oleh para ahli beranekaragam, dan

\footnotetext{
5 “Undang-Undang Republik Indonesia Nomor 20 Tahun 2003 Tentang Sistem Pendidikan Nasional Pasal 1 Ayat (1)," n.d.
} 
kandungannya berbeda satu dari yang lainnya. ${ }^{6}$

Batasan pendidikan yang berbeda berdasarkan fungsinya adalah (a) Pendidikan sebagai proses transformasi budaya, pendidikan diartikan sebagai kegiatan pewarisan budaya dari satu generasi ke generasi yang lain; (b) Pendidikan sebagi proses pembentukan pribadi, pendidikan diartikan sebagai suatu kegiatan yang sistematis dan sistemik terarah kepada terbentuknya kepribadian peserta didik; (c) Pendidikan sebagai proses penyiapan warga negara, pendidikan diartikan sebagai suatu kegiatan yang terencana untuk membekali peserta didik agar menjadi warga negara yang baik; (d) Pendidikan sebagai penyiapan tenaga kerja, pendidikan diartikan sebagai kegiatan membimbing peserta didik sehingga memiliki bekal dasar untuk bekerja.

Pendidikan memegang peranan penting dalam kehidupan, baik individu maupun masyarakat, dan tidak dapat dipisahkan dari kehidupan masyarakat. Kebutuhan akan pendidikan dari masyarakat semakin hari semakin meningkat, sesuai dengan perkembangan zaman. Pendidikan erat kaitannya dengan nilai-nilai yang ada dalam masyarakat dan kebudayaan. Jadi bagaimanapun sederhananya peradapan suatu masyarakat, di dalamnya berlangsung suatu proses pendidikan. Menurut Ki Hajar Dewantara menyatakan bahwa pengertian pendidikan adalah sebagai daya upaya untuk memberikan tuntunan pada segala kekuatan kodrat yang pada

\footnotetext{
${ }^{6}$ Tirtaraharja Umar La Sulo and Umar Tirtarahardja, "Pengantar Pendidikan," Jakarta: PT. Rineka, 2005.
}

anak-anak, agar mereka baik sebagai manusia maupun sebagai anggota masyarakat dapatlah mencapai keselamatan dan kebahagiaan hidup lahir batin yang setinggi-tingginya.

Pendidikan menurut Deweyadalah proses pembentukan kecakapan fundamental secara intelektual dan emosional kearah alam dan sesama manusia. $^{7}$ Menurut Ki Supriyoko, pendidikan adalah strategi untuk meningkatkan kualitas manusia. ${ }^{8}$

Dari pengertian diatas kemudian dapat disimpulkan bahwa; (1) pendidikan adalah aktivitas manusia; (2) untuk memberikan tuntunan, bimbingan, pengajaran, dan latihan; 3) dilakukan dengan sengaja, teratur, dan berencana; 4) perjanjian mengubah tingkah laku anak didik ke arah kedewasaan.

Karakter berasal dari bahasa Yunani yang berarti to mark atau menandai dan memfokuskan bagai-mana mengaplikasikan nilai kebaikan dalam bentuk tindakan atau tingkah laku, sehingga orang yang tidak jujur, kejam, rakus, dan perilaku jelek lainnya dikatakan orang berkarakter jelek. Sebaliknya, orang yang perilakunya sesuai dengan kaidah moral disebut dengan berkarakter mulia. ${ }^{9}$

Karakter mulia berarti individu memiliki pengetahuan tentang potensi dirinya, yang ditandai dengan nilai-nilai seperti reflektif, percaya diri, rasional, logis, kritis, analitis, kreatif dan inovatif,

\footnotetext{
${ }^{7}$ Rahmi, "Kontribusi Matematika Dalam Pembentukan Karakter Siswa," Jurnal Ekotrans 12 No. 1 (2013).

${ }^{8}$ Ibid.

${ }^{9}$ Edi Saputra, "Eksistensi PKn Sebagai Pendidikan Nilai Dalam Membangun Karakter Bangsa," TINGKAP 8, no. 2 (2012): 145-158.
} 
mandiri, hidup sehat, bertanggung jawab, cinta ilmu, sabar, berhati-hati, rela berkorban, pemberani, dapat dipercaya, jujur, menepati janji, adil, rendah hati, malu berbuat salah, pemaaf, berhati lembut, setia, bekerja keras, tekun, ulet/gigih, teliti, berinisiatif, berpikir positif, disiplin, antisipatif, inisiatif, visioner, bersahaja, bersemangat, dinamis, hemat/efisien, menghargai waktu, pengabdian/ dedikatif, pengendalian diri, produktif, ramah, cinta keindahan (estetis), sportif, tabah, terbuka, tertib. Individu juga memiliki kesadaran untuk berbuat yang terbaik atau unggul, dan individu jugamampu bertindak sesuai potensi dan kesadarannya tersebut. Karakteristik adalah realisasi perkembangan positif sebagai individu (intelektual, emosional, sosial, etika, dan perilaku). Individu yang berkarakter baik atau unggul adalah seseorang yang berusaha melakukan hal-hal yang terbaik terhadap Tuhan Yang Maha Esa, dirinya, sesama, lingkungan, bangsa dan negara serta dunia internasional pada umumnya dengan mengoptimalkan potensi (pengetahuan) dirinya dan disertai dengan kesadaran, emosi dan motivasinya (perasaannya).

Menurut Ghufron karakter adalah jati diri, kepribadian dan watak yangmelekat ada diri seseorang. Karakter selalu melekat dengan dimensi fisik dan psikis individu. Karakter bangsa yang merupakan jati diri yang meruakan kumulasi dari karakter karakter warga masyarakat suatu bangsa. ${ }^{10}$

\footnotetext{
${ }^{10}$ Anik Ghufron, "Integrasi Nilai-Nilai Karakter Bangsa Pada Kegiatan Pembelajaran," Cakrawala Pendidikan 29 (2010): 13-24.
}

Pendidikan karakter adalah suatu sistem penanaman nilai-nilai karakter kepada warga sekolah yang meliputi komponen pengetahuan, kesadaran atau kemauan, dan tindakan untuk melaksankan nilai-nilai tersebut, baik terhadap Tuhan Yang Maha Esa (TYME), diri sendiri, sesama lingkungan, maupun kebangsaan, sehingga menjadi insan kamil. Pendidikan karakter dapat dimaknai sebagai budi pekerti yaitu yang melibatkan aspek pengetahuan (cognitive), sikap (affective) perasaan (felling) dan tindakan. Menurut Thomas Likona tanpa ketiga aspek tersebut pendidikankarakter tidak akan efektif. ${ }^{11}$

Alur pikir pembangungan karakter menempatkanpendidikan menjadi salah satu strategi dasar daripembangunan karakter bangsa yang dalam pelaksanaanyaharus dilakukan secara koheren dengan beberapa strategiyang mencakup sosialisasi atau penyadaran,pemberdayaan, pembudayaan dan kerjasama seluruhkomponen bangsa. Pembangunan karakter dilakukandengan pendekatan sistematik dan integratif denganmelibatkan keluarga, satuan pendidikan, pemerintah,masyarakat sipil, anggota legislatif, media massa, duniausaha dan industri (Kemdiknas, 2011:6), seperti terlihatpada bagan berikut:

\footnotetext{
${ }^{11}$ Rifki Afandi, "Integrasi Pendidikan Karakter Dalam Pembelajaran IPS Di Sekolah Dasar," PEDAGOGIA 1, no. 1 (2016): 85-98.
} 


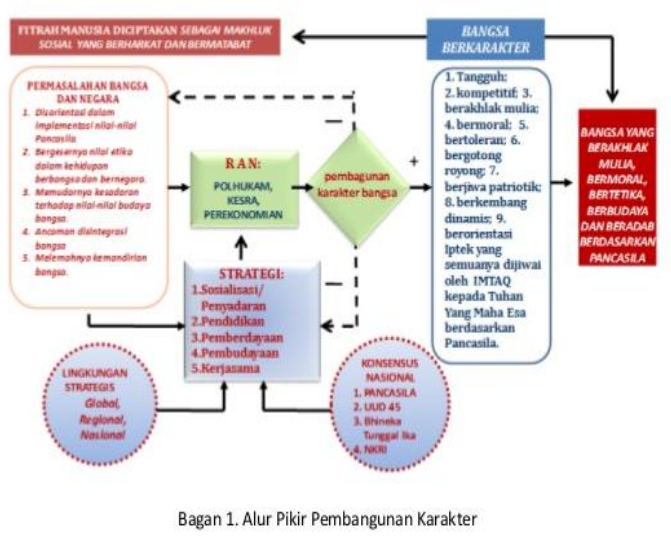

Berdasarkan alur pikir bagan tersebut diatas, pendidikan merupakan salah satu strategi dasar dari pembengunan karakter bangsa yang dalam pelaksanaannya harus dilakukan secara koheren dengan beberapa strategi lain. Strategi tersebut mencakup sosialisasi atau penyadaran, pemberdayaan, pembudayaan, dan kerjasama seluruh komponen bangsa. Pembangunan karakter dilakukan dengan pendekatan sistematik dan integratif dengan melibatkan keluarga, satuan pendidikan, pemerintah, masyarakat, dan dunia industri. (sumber: buku induk pembangunan karakter, 2010)

\section{TUJUAN PENDIDIKAN KEWARGA- NEGARAAN}

Berdasarkan keputusan DIRJEN DIKTI NO 43/DIKTI/Kep/2006, tujuan Pendidikan Kewarganegaraan adalah dirumuskan dalam visi, misi dan kompetensi sebagai berikut:

a. Visi, pendidikan kewargane-garaan di perguruan tinggi adalah merupakan sumber nilai dan pedoman dalam pengembangan dan penyelenggaraan program studi, guna mengantarkan mahasiswa memantapkan kepribadiannya sebagai manusia seutuhnya. Hal ini berdasarkan pada suatu realitas yang dihadapi, bahwa mahasiswa adalah sebagai generasi bangsa yang harus memiliki visi intelektual, religius, berkeadaban, berkemanusiaan dan cinta tanah air dan bangsanya.

b. Misi, Pendidikan Kewarganegaraan di perguruan tinggi adalah untuk membantu mahasiswa memantabkan kepribadiannya, agar secara konsisten mampu mewujudkan nilai-nilai dasar Pancasila, rasa kebangsaan dan cinta tanah air dalam menguasai, menerapkan dan mengembangkan ilmu pengetahuan, teknologi dan seni dengan rasa tanggung jawab dan bermoral.

Oleh karena itu kompetensi yang diharapkan mahasiswa adalah untuk menjadi ilmuwan dan profesional yang memiliki rasa kebangsaan dan cinta tanah air, demokratis, berkeadaban. Selain itu kompetensi yang diharapkan agar mahasiswa menjadi warganegara yang memiliki daya saing, berdisiplin, berpartisipasi aktif dalam membangun kehidupan yang damai berdasarkan sistem nilai Pancasila. ${ }^{12}$

Ruang lingkup Pendidikan Kewarganegaraan di perguruan tinggi meliputi substansi kajian sebagai berikut: 13

\section{1) Hakikat pendidikan kewarga- negaran dalam pengembangan}

\footnotetext{
${ }^{12}$ Kaelan \& Zubaidi, "Pendidikan Kewarganegaraan Untuk Perguruan Tinggi."

13 "Pedoman Matakuliah Pendidikan

Kewarganegaraan (Pkn) Sebagai Mata Kuliah Wajib Umum (MKWU)."
} 
kemampuan utuh sarjana atau profesional.

2) Esensi dan urgensi identitas nasional sebagai salah satu determinan dalam pembangunan bangsa dan karakter yang bersumber dari nilai-nilai Pancasila

3) Urgensi integrasi nasional sebagai salah satu parameter persatuan dan kesatuan bangsa dalam wadah Negara Kesatuan Republik Indonesia.

4) Nilai dan norma yang terkandung dalam konstitusi di Indonesia dan konstitusionalitas ketentuan di bawah UUD dalam konteks kehidupan bernegarakebangsaan Indonesia

5) Harmoni kewajiban dan hak negara dan warga negara dalam tatanankehidupan demokrasi Indonesia yang bersumbu pada kedaulatan rakyat dan musyawarah untuk mufakat.

6) Hakikat, instrumentasi, dan praksis demokrasi Indonesia yang bersumber dari Pancasila dan Undang-Undang Dasar Negara Republik Indonesia Tahun 1945 sebagai wahana penyelenggaran negara yang sejahtera dan berkeadilan.

7) Dinamika historis konstitusional, sosiaL-politik, kultural, serta konteks kontemporer penegakan hukum dalam konteks pembangunan negara hukumyang berkeadilan.

8) Dinamika historis, dan urgensi Wawasan Nusantara sebagai konsepsi dan pandangan kolektif kebangsaan Indonesia dalam konteks pergaulan dunia.

9) Urgensi dan tantangan ketahanan nasional bagi Indonesia dalam membangun komitmen kolektif yang kuat dari seluruh komponen bangsa untuk mengisi kemerdekaan Indonesia.

Pendidikan Kewarganegaraan bertujuan mengembangkan kompetensi warga negara dalam berpartisipasi secara bertanggung jawab serta sesuai dengan konstitusi (UUD 1945) yang dikembangkan di era reformasi ini menduduki posisi strategis dalam karakter kebangsaan. Dengan kata lain nation and character building merupakan visi mengIndonesiakan orang Indonesia. Sebab meskipun secara yuridis formal seseorang berstatus sebagai WNI tetapi dikhawatirkan karakternya bukan sebagai bangsa Indonesia, misalkan berkarakter liberalis, otoriter, dan anarkis. Pendidikan Kewarganegaraan bertujuan untuk mendidik kebangsaan warga negara dalam masyarakat pluralis untuk menjamin integrasi bangsa dalam bingkai kesatuan dalam keberagaman. Pendidikan Kewarganegaraan termasuk pendidikan kebangsaan yang sangat progressif, sebab dalam pengembangan karakter kebangsaan tidak sebatas pada cultural nation tetapi juga pada political nation.

\section{EKSISITENSI PENDIDIKAN KEWARGA- NEGARAAN}

Perjuangan bangsa Indonesia dimulai dari masa sebelum dan selama penjajahan, dilanjutkan dengan merebut kemerdekaan hingga mengisi kemerdekaan. Setiap tahapan tersebut 
melahirkan tantangan yang berbeda sesuai dengan kondisi masa saat itu. Tantangan jaman ditanggapi oleh bangsa Indonesia berdasarkan kesamaan nilainilai perjuangan bangsa, yang dilandasi dengan jiwa dan tekad kebangsaan. Kesemuanya itu tumbuh dan berkembang menjadi kekuatan yang mampu mendorong proses terwujudnya NKRI.

Eksistensi

Pendidikan

Kewarganegaraan dalam memperkokoh karakter bangsa Indonesia di lingkup perguruan tinggi bisa dilihat dari beberapa perspektif, diantaranya perspektif akademik, perspektif yuridis dan perspektif politis.

a. Perspektif Akademik,

Pendidikan Kewarganegaraan (PKn) memiliki visi sebagai nation and character building. Yakni membangun karakter manusia Indonesia yang Pancasilais, karena ideologi Pancasila merupakan identitas bagi bangsa Indonesia.Selain berdimensi identitas, Pancasila juga berdimensi humanitas (sila kedua dankeempat) dan universalitas (sila pertama dan keempat). ${ }^{14}$ Ketika Indonesia menjadi negara merdeka, proses menjadi bangsaIndonesia terus berlangsung. Perjalanan sebagai negara merdeka, Negara Indonesia sering dihadapkan pada konflik sosial yang keras dan gerakan separatis yang sangat potensial menimbulkan disintegrasi bangsa. Dengan demikian Pendidikan Kewarganegaraan sangat diperlukan demi keberlangsungan dan kejayaan Bangsa Indonesia yang memiliki karakter berdasarkan Pancasila.

b. Perspektif Yuridis

\footnotetext{
${ }^{14}$ Sartono Kartodirdjo, Pembangunan Bangsa (Aditya Media, 1994).
}

Eksistensi mata kuliah Pendidikan Kewarganegaraan di perguruan tinggi secara yuridis berpijak pada ketentuan perundang-undangan sebagai berikut: 15

1) Undang Undang Dasar Negara Republik Indonesia Tahun 1945;

2) Undang Undang Nomor 20 Tahun 2003 tentang Sistem Pendidikan Nasional

3) Undang Undang nomor 12 Tahun 2012 tentang Pendidikan Tinggi

4) Undang Undang nomor 17 Tahun 2007 tentang Rencana Pembangunan JangkaPanjang 2005-2025.

5) Peraturan Pemerintah Republik Indonesia Nomor 19 Tahun 2005 sebagaimana telahdiubah dengan Peraturan Pemerintah RI Nomor 032 Tahun 2013 tentang Standar Nasional Pendidikan.

6) Peraturan Pemerintah Republik Indonesia Nomor 5 Tahun 2010 tentang RencanaPembangunan Jangka Menengah Nasional 20102014.

7) Permendikbud No 49 Tahun 2014 tentang Standar Nasional Pendidikan Tinggi

8) Surat Keputusan Dirjen Dikti Depdiknas RI No. 43 /Dikti/Kep/2006 Tentang RambuRambu Pelaksanaan Kelompok Mata Kuliah Pengembangan Kepribadian diPerguruan Tinggi.

9) Surat Edaran Dirjen Dikti No 914/E/T/2011 tentang Penyelenggaraan

\footnotetext{
15 "Pedoman Matakuliah Pendidikan Kewarganegaraan (Pkn) Sebagai Mata Kuliah Wajib Umum (MKWU).”
} 
PerkuliahanPendidikan Pancasila di

Perguruan Tinggi.

c. Perspektif Politis

Pendidikan Kewarganegaraan secara akademis memiliki akar keilmuan yang jelas yakni ilmu politik, artinya Pendidikan Kewarganegaraan tidak akan rentan dari pengaruh baik dari dalam maupun luar yang sekiranya dapat merongrong karakter bangsa Indonesia. Oleh karenanya akar ilmu Pendidikan yang jelas serta pembahasan materi yang jelas akan memperkokoh karakter dari generasi bangsa khususnya para pelajar dan mahasiswa. Karena merekalah yang akan mengisi kursi kepemimpinan kedepannya untuk memperbaiki citra karakter pemimpin saat ini yang sebagian besar sangat mencederai bangsa Indonesia.

Untuk perguruan tinggi, sesuai dengan amanat Undang-Undang Nomor 12 Tahun

2012, dikemas dan diwadahi dalam dua mata kuliah yakni mata kuliah Pendidikan Pancasila yang lebih menekankan pada pendekatan filosofis-ideologis dan sosioandragogis dalam konteks nilai ideal dan istrumental Pancasila dan UUD NRI1945, dan mata kuliah Pendidikan Kewarganegaraan yang lebih menekankan pada pendekatan psiko-andragogis dan sosio-kultural dalam konteks nilai instrumental dan praksis Pancasila dan UUD NRI 1945, serta nilai kontemporer kosmopolitanisme. ${ }^{16}$

Secara paradigmatik kurikuler irisan antara pendidikan Pancasiladan Pendidikan Kewarganegaraan di

\footnotetext{
${ }^{16}$ Ibid.
}

perguruan tinggi dapat digambarkan sebagai berikut: ${ }^{17}$

1. Pancasila ditempatkan dan dimaknai sebagai entitas inti yang menjadi sumber rujukan dan ukuran keberhasilan dari keseluruhan ruang lingkup mata kuliah Pendidikan Pancasila dan Pendidikan Kewarganegaraan.

2. Undang Undang Dasar Negara Republik Indonesia Tahun 1945, Bhinneka Tunggal Ika dan Negara Kesatuan Republik Indonesia ditempatkan sebagai bagian integral dari pembangunan kehidupan dan penyelenggaraan negara yang berdasarkan atas Pancasila.

Dengan adanya perkembangan baru dalam pengorganisasian pendidikan kewarganegaraan tersebut, terdapat kebutuhan dan tantangan baru bagi semua dosen Pendidikan Kewarganegaraan sebagai berikut: 18

1. Penguatan dan penyempurnaan PKn secara komprehensif memberi tantangan sekaligus menimbulkan implikasi terhadap peningkatan kualifikasi, kompetensi, sertifikasi, dan kinerja dosen PKn secara berkelanjutan. Dosen dituntutmenguasai secara mendalam dan komprehensif latar belakang dan semangat perubahan tersebut mulai dari nama, visi misi, substansi, strategi pembelajaran,dan penilaian PKn. Penguatan kurikulum PKn ini juga menuntut adanya perubahan pola pikir, pola sikap dan pola tindak,

\footnotetext{
17 Ibid.

${ }^{18}$ Ibid.
} 
serta budaya profesional guru, terkait dimensi pengetahuan kewarganegaraan, sikap kewarganegaraan, keterampilan kewarganegaraan, keteguhan kewarganegaraan, komitmen kewarganegaraan, dan kompetensi kewarganegaraan.

2. Penetapan adanya dua mata kuliah wajib umum di perguruan tinggi memberi tantangan sekaligus menimbulkan implikasi terhadap penyegaran, pengadaan dosen Pendidikan Pancasila dan dosen Pendidikan Kewarganegaraan secara berkelanjutan. Dosen dituntut menguasai secara mendalam dan komprehensif latar belakang dan yang terkandung dalam visi, misi, substansi, strategi, pembelajaran, dan penilaian Pendidikan Pancasila dan Pendidikan Kewarganegaraan. Penguatan profesionalisme dosen ini juga menuntut adanya perubahan pola pikir, pola sikap dan pola tindak, serta budaya profesional guru, terkait dimensi pengetahuan kewarganegaraan, sikap kewarganegaraan, keterampilan kewarganegaraan, keteguhan kewarganegaraan, komitmen kewarganegaraan, dan kompetensi kewarganegaraan yang seyogyanya dimiliki oleh para dosen tersebut.

\section{URGENSI PENDIDIKAN KEWARGA- NEGARAAN DALAM MEMPERKOKOH KARAKTER BANGSA}

Dalam konteks pembangunan bangsa dan karakter (nation and character building) pendidikan kewarganegaraan dalam arti luas memiliki kedudukan, fungsi, dan peranyang sangat penting. Pendidikan kewarganegaraan pada dasarnya merupakan salahsatu bentuk pendidikan karakter yang dikembangkan secara sistematis dan sistemik.Dalam konteks itu pendidikan kewarganegaraan tidak bisa dipisahkan dari kerangkakebijakan nasional pembangunan bangsa dan karakter.

Pendidikan kewarganegaraan sangat penting untuk menanamkan nilainilai cinta tanah air, moralitas, dan jiwa kebangsaan yang menjadi identitas dan karakter bangsa dalam mencapai integritas bangsa, sehingga dijadikan sebagai dasar yang kuat dan kokoh untuk mengembangkan dan membina kepribadian pada generasi muda bahkan setiap warga negara Indonesia. ${ }^{19}$

Pendidikan kewarganegaraan mengembangkan nilai-nilai dan mendorong kesadaran terhadap hak dan kewajiban warga negara serta mengimplementasikannya dalam kehidupan bermasyarakat, berbangsa dan bernegara. Konstitusi Negara Republik Indonesia perlu ditanamkan kepada seluruh komponen bangsa Indonesia, khususnya generasi muda sebagai generasi penerus. Indonesia harus menghindari sistem pemerintahan otoriter yang memeasung hak-hak warga negara untuk menjalankan prinsip-prinsip demokrasi dalam kehidupan bermasyarakat, berbangsa dan bernegara. $^{20}$

\footnotetext{
${ }^{19}$ Arif Mansyuri, Kewarganegaraan (Sidoarjo: Masmadia Buana Pustaka, 2012), 17. ${ }^{20}$ Ibid.
} 
Kehidupan yang demokratis di dalam kehidupan sehari-hari dilingkungan keluarga, sekolah, masyarakat, pemerintaan, dan organisasiorganisasi non pemerintahan perlu dikenal, dipahami, diinternalisasi dan diterapkan demi terwujudnya pelaksanaan prinsip-prinsip demokrasi. Selain itu, perlu pula ditanamkan kesadaran bela negara, penghargaan terhadap hak asasi manusia, kemajemukan bangsa, pelestarian lingkungan hidup, tanggung jawab sosial, ketaatan pada hukum, ketaatan membayar pajak, serta sikap dan perilaku anti korupsi, kolusi dan nepotisme. ${ }^{21}$

Pendidikan kewarganegaraan begitu sangat penting, maka senantiasa tidak hanya untuk dipahami semata namun wajib diimplementasikan dalam kehidupan sehari-hari dilingkungan keluarga dan lingkungan masyarakat secara luas.Perkembangan globalisasi yang ditandai dengan kuatnya pengaruh lembaga-lembaga kemasyarakatan internasional dan pengaruh negara-negara lain dalam percaturan politik, ekonomi, sosial-budaya, agama, pendidikan, ketahanan dan keamanan. Kondisi demikian akan banyak meimbulkan berbagai konflik kepentingan, baik antara sesama warga negara, sesama negara maju, negara maju dengan negara berkembang, sesama negara berkembang maupun antar lembaga lembaga nasional maupun internasional.

Indonesia saat ini negara dan bangsa dihadapkan pada permasalahan pokok yaitu yang pertama, tantangan dan pusaran globalisasi; kedua, masalah

\footnotetext{
${ }^{21}$ Ibid., 17-18.
}

internal seperti KKN, destibilisasi, separatisme, teror dan sebagainya; dan ketiga, bagaimana menjaga "roh" reformasi tetap berjalan pada relnya. Atas dasar itu maka perlu ada langkah-langkah strategis, yaitu; pertama, reformasi sistem yang menyangkut perumusan kembali falsafah, kerangka dasar dan perangkat legal sistem politik; kedua, reformasi kelembagaan yang menyangkut pengembangan dan pemberdayaan lembaga-lembaga politik dan ketiga, pengembangan kultur atau budaya politik yang lebih demokratis dan tertanamnya komitmen untuk lebih baik. ${ }^{22}$

Apabila yang pertama dan kedua lebih didominasi oleh eksekutif dan legislatif, yang ketiga harus dilakukan oleh seluruh elemen masyarakat mulai dari masyarakat sipil sampai elit politik. Pemberdayaan ini harus dilakukan secara menyeluruh, berkesinambungan dan dalam bingkai paradigma yang jelas. Adapun media yang dianggap tepat untuk mencapai sasaran tersebut salah satunya adalah melalui pembelajaran civic education (Pendidikan Kewarganegaraan). Di tingkat perguruan tinggi, nilai strategis dari pembelajaran ini ialah meningkatnya kesadaran komprehensif mahasiswa terhadap masalah bangsa. Pada gilirannya hal itu akan berujung pada keterlibatan (partisipasi efektif) dan tumbuhnya kesadaran tanggung jawab untuk memperbaiki kualitas hidup sosial dan politik secara keseluruhan.

Falsafah Pancasila merupakan identitas nasional bangsa Indonesia. Nilainilai luhur kepribadian bangsa Indonesia

\footnotetext{
${ }^{22}$ Misbahul Munir and Amirulloh, Kewarganegaraan (Sidoarjo: Masmedia Buana Pustaka, 2011), 24.
} 
yang terdapat dalam falsafah Pancasila diantaranya adalah sikap sopan santun, saling menghargai, saling menghormati, menjunjung tinggi hak asasi manusia, bergotong royong, patriotisme dan nasionalisme, serta berkeadilan di semua bidang kehidupan. Maka dari itu, dalam berkehidupan berbangsa dan bernegara senantiasa harus berpegang teguh kepada Pancasila di berbagai aspek kehidupan. Senada dengan apa yang dikemukakan oleh Teguh Prasetyo; "Dengan demikian Pancasila merupakan norma tertinggi yang kedudukannya lebih tinggidari konstitusi atau UUD,". ${ }^{23}$ Penempatan Pancasila sebagai norma tertinggi harus dijadikan sebagai pemandu bagi setiap pembentukan norma hukum di Indonesia, sehingga secara hierarki norma yang lebih rendah tidak boleh bertentangan dengan norma hukum yang lebih tinggi. Dengan demikian, sudah dapat dipastikan karakter bangsa Indonesia dapat kokoh, walaupun diterpa tantangan yang datang silih berganti bangsa Indonesia tidak bisa goyah. Kokoh disini mengandung makna kuat, tangguh, teguh pendirian, tidak mudah terombang ambing, tidak mudah putus asa, tegar, bisa mengatasi masalah sesuai dengan nilai-nilai Pancasila yang merupakan kepribadian bangsa Indonesia.

$\begin{array}{ccc}\begin{array}{c}\text { Setiap } \\ \text { warga negara dalam } \\ \text { bermasyarakat }\end{array} & \text { harus }\end{array}$
memperhatikan dan melaksanakan (mentaati) peraturan hukum, agar tercipta kehidupan yang tertib dan tenteram. Kalau terjadi pelanggaran terhadap peraturan hukum yang berlaku, peraturan yang

\footnotetext{
${ }^{23}$ Teguh Prasetyo, "Hukum Dan Sistem Hukum Berdasarkan Pancasila," Cetakan Pertama, Yogyakarta: Media Perkasa, 2013, 70.
}

dilanggar itu harus ditegakkan. Dari uraian diatas penulis berharap tidak akan ada lagi yang namanya penegakan hukum masih diwarnai dengan kecurangan oleh aparat hukum Indonesia diantaranya kepolisian, kejaksaan, pengadilan serta lembaga kemasyarakatan. Pandangan keadilan dalam hukum nasional bersumber pada dasar negara. Pancasila sebagai dasar negara atau falsafah negara (fiolosofische grondslag) sampai sekarang tetap dipertahankan dan masih tetap penting bagi negara Indonesia. Secara aksiologis, bangsa Indonesia merupakan pendukung nilai-nilai Pancasila (subcriber of values Pancasila). Bangsa Indonesia yang berketuhanan, yang berkemanusiaan, yang berpersatuan, yang berkerakyatan, dan yang berkeadilan sosial. ${ }^{24}$

Upaya memperkokoh karakter bangsa Indonesia melalui implementasi pendidikan kewarganegaraan maka bisa dilihat bahwa pendidikan karakter telah mengidentifikasi 18 nilai yang bersumber dari agama, Pancasila, budaya, dan tujuan pendidikan nasional, yaitu: ${ }^{25}$

1) Religius, perilaku yang didasarkan pada upaya menjadikan dirinya sebagai orang yang selalu dapat dipercaya dalam perkataan, tindakan, dan pekerjaan.

2) Jujur, perilaku yang didasarkan pada upaya menjadikan dirinya sebagai orang yang selalu dapat

\footnotetext{
${ }^{24}$ Farida Sekti Pahlevi, "REVITALISASI PANCASILA DALAM PENEGAKAN HUKUM YANG BERKEADILAN DI INDONESIA," Justicia Islamica 13, no. 2 (2016),

http://jurnal.stainponorogo.ac.id/index.php/justicia/arti cle/view/585.

${ }^{25}$ Afandi, "Integrasi Pendidikan Karakter Dalam Pembelajaran IPS Di Sekolah Dasar."
} 
dipercaya dalam perkataan, tindakan dan pekerjaan.

3) Toleransi, sikap dan tindakan menghargai perbedaan agama, suku, etnis, pendapat, sikap dan tindakan orang lain yang berbeda dari dirinya.

4) Disiplin, tindakan yang menunjukkan perilaku tertib dan patuh pada berbagai ketentuan dan peraturan

5) Kerja keras, perilaku yang menujukkan upaya sunggungsungguh dalam mengatasi berbagai hambatan belajar dan tugas serta menyelesaikan tugas dengan sebaik-baiknya.

6) Kreatif, berpikir dan melakukan sesuatu yang menghasilkan cara atau hasil baru berdasarkan apa yang telah dimiliki.

7) Mandiri, sikap dan perilaku yang tidak mudah tergantung pada orang lain dalam menyelesaikan tugastugas.

8) Demokratis, cara berfikir, bersikap dan bertindak yang menilai sama hak dan kewajiban dirinya dan orang lain.

9) Rasa ingin tahu, sikap dan tindakan yang selalu berupaya untuk mengetahui lebih mendalam dan meluas dari apa yang dipelajarinya, dilihat dan didengar.

10) Semangat kebangsaan, cara berfikir, bertindak dan wawasan yang menempatkan kepentingan bangsa dan negara di atas kepentingan diri dan kelompoknya.

11) Cinta tanah air, cara berfikir, bersikap dan berbuat yang menunjukkan kesetiaan, kepedulian, dan penghargaan yang tinggi terhadap bahasa, lingkungan fisik, sosial, budaya, ekonomi dan politik bangsanya.

12) Menghargai prestasi, sikap dan tindakan yang mendorong dirinya untuk menghasilkan sesuatu yang berguna bagi masyarakat, mengakui dan menghormati keberhasilan orang lain.

13) Bersahabat/komunikatif, tindakan yang memperlihatkan rasa senang berbicara, bergaul dan bekerjasama dengan orang lain.

14) Cinta damai, sikap, perkataan dan tindakan yang menyebabkan orang lain merasa senang dan aman atas kehadiran dirinya.

15) Senang membaca, kebiasaan menyediakan waktu untuk membaca berbagai bacaan yang memberikan kebajikan bagi dirinya.

16) Peduli sosial, sikap dan tindakan yang selalu ingin memberi bantuan kepada orang lain dan masyarakat yang membutuhkan.

17) Peduli lingkungan, sikap dan tindakan yang selalu berupaya mencegah kerusakan lingkungan alam di sekitarnya, dan mengembangkan upaya-upaya untuk memperbaiki kerusakan alam yang sudah terjadi.

18) Tanggung jawab, sikap dan perilaku seseorang untuk melaksanakan tugas dan kewajibannya, yang seharusnya dia lakukan, terhadap dirinya sendiri, masyarakat, lingkungan (alam sosial dan budaya), negara dan Tuhan Yang Maha Esa. 
Pendidikan Kewarganegaraan (civic education) pada masa globalisasi ini haruslah dimaknai sebagai jalan yang diharapkan akan mampu mengantar bangsa Indonesia menciptakan bangsa yang berkarakter berdasarkan Pancasila sehingga demokrasi, good governance, negara hukum dan masyarakat sipil yang relevan dengan tuntutan global bisa terwujud. Tentunya ekspektasi ini harus disertai dengan tindakan nyata bangsa ini, khususnya dalam lingkup Perguruan Tinggi untuk mengapresiasi dan mengimplementasikan Pendidikan Kewarganegaraan dalam dunia pendidikan secara maksimal. Jadi, hasil pembelajaran Pendidikan Kewarganegaraan (civic education) sangat penting artinya untuk mewujudkan generasi bangsa yang memiliki karakter kokoh dalam menghadapi segala tantangan yang datang silih berganti.Untuk mencapai tujuan pendidikan kewarganegaraan seperti tersebutdi atas, sangat dibutuhkan model dan strategi pembelajaran yang humanistik yang mendasarkan pada asumsi bahwa mahasiswa adalah manusia yang mempunyai potensi dan karakteristik yang berbeda-beda. Mahasiswa diposisikan sebagai subjek, sementara dosen diposisikan sebagai fasilitator dan mitra dialog mahasiswa. Materi hendaknya disusun berdasarkan kebutuhan dasar mahasiswa, bersifat fleksibel, dinamis dan fenomenologis sehingga materi tersebut bersifat kontekstual dan relevan dengan tuntutan dan perubahan masyarakat lokal, nasional, dan global.
Pendidikan kewarganegaraan (civic education ) harus mampu menjadikan dirinya sebagai salah satu instrumen pendidikan untuk pemberdayaan bagi masyarakat, terutama peserta didik yang sedang dalam proses pembelajaran pendidikan ini. Selain itu, pendidikan kewarganegaraan harus dapat dijadikan wahana dan instrumen untuk melakukan social enginering dalam rangka membangun modal sosial yang efektif bagi tumbuhnya kultur demokrasi dalam kehidupan masyarakat, berbangsa dan bernegara serta tumbuhnya masyarakat madani yang memiliki karakter kokoh. ${ }^{26}$

Solusi yang ditawarkan dalam kerangka pendidikan kewarganegraaan yang berkeadaban adalah metode dan proses pendidikan yang tidak saja memberikan pengetahuan, akan tetapi juga aktivitas untuk membangun kesadaran, kedewasaan, kemandirian, serta pembebasan. Karakter yang disebutkan pada nilai-nilai terakhir inilah yang merupakan hakikat pendidikan dan demokrasi atau pendidikan kewargaan. ${ }^{27}$

Perlu digarisbawahi juga bahwa setiap negara sangat memerlukan warga negara yang bertanggung jawab. Penanaman pendidikan kewarganegaraan akan menciptakan warga negara yang sadar akan hak dan kewajibannya serta memiliki karakter bangsa Indonesia yang kokoh. Dengan demikian, bangsa dan negara Indonesia tidak akan bisa diombang ambingkan oleh pengaruh yang

\footnotetext{
${ }^{26}$ Jazim Hamidi and Mustafa Lutfi, Civic Education: Antara Realitas Politik Dan Implementasi Hukumnya (PT Gramedia Pustaka Utama, 2010), 128-29. ${ }^{27}$ Ibid.
} 
mengancam keutuhan serta kejayaan NKRI.

\section{PENUTUP}

Bangsa Indonesia harus kuat dalam menghadapi tantangan dari berbagai penjuru di era globalisasi ini. Terwujudnya bangsa Indonesia berkarakter yang kokoh digambarkan oleh baik dan buruknya segala hal yang dilakukan oleh bangsa Indonesia serta mampu tidaknya menghadapi ujian yang datang silih berganti di berbagai aspek kehidupan. Sejalan dengan tujuan pendidikan kewarganegaraan membentuk kepribadian yang sesuai dengan Pancasila dan karakter bangsa Indonesia maka, disaat ingin menjadi bangsa yang berkualitas hendaknya lebih memperhatikan semua aspekkehidupan, baik melalui pendidikan formal, informal, dan non formal. Perguruan tinggi mempunyai peran yang cukup besar, mempersiapkan generasi bangsa yang akan menjadi tonggak keberlangsungan, kejayaan dan kemajuan Bangsa dan Negara Indonesia. Sehingga dalam proses pembelajaran dihimbau agar tidak hanya melakukan transfer pengetahuan semata, akan tetapi harus diimbangi dengan implementasi sesuai dengan tujuan dan cita- cita Negara Kesatuan Republik Indonesia.

\section{DAFTAR PUSTAKA}

Afandi, Rifki. "Integrasi Pendidikan Karakter Dalam Pembelajaran IPS Di Sekolah Dasar." PEDAGOGIA 1, no. 1 (2016): 85-98.
Darani, Karuna. Accessed April 2, 2017. http://www.kompasiana.com/karu nadarani/pentingnya-pendidikan kewarganegaraan-di-perguruantinggi-pada-era globalisasi_54f76d8aa33311d6338 b495d.

Ghufron, Anik. "Integrasi Nilai-Nilai Karakter Bangsa Pada Kegiatan Pembelajaran." Cakrawala Pendidikan 29 (2010): 13-24.

Hamidi, Jazim, and Mustafa Lutfi. Civic Education: Antara Realitas Politik Dan Implementasi Hukumnya. PT Gramedia Pustaka Utama, 2010.

Kaelan \& Zubaidi, Ahmad. "Pendidikan Kewarganegaraan Untuk Perguruan Tinggi." Yogyakarta: Paradigma, 2007.

Kartodirdjo, Sartono. Pembangunan Bangsa. Aditya Media, 1994.

La Sulo, Tirtaraharja Umar, and Umar Tirtarahardja. "Pengantar Pendidikan." Jakarta: PT. Rineka, 2005.

Mansyuri, Arif. Kewarganegaraan.

Sidoarjo: Masmadia Buana Pustaka, 2012.

Munir, Misbahul, and Amirulloh.

Kewarganegaraan. Sidoarjo:

Masmedia Buana Pustaka, 2011.

Pahlevi, Farida Sekti. "REAKTUALISASI

PANCASILA SEBAGAI UPAYA PENINGKATAN KUALITAS

PENDIDIKAN MORAL BANGSA INDONESIA." Al-Adabiya: Jurnal Kebudayaan Dan Keagamaan 9, no. 1 (2014): 21-44.

$\begin{array}{crr}-1 & \text { "REVITALISASI } & \text { PANCASILA } \\ \text { DALAM } & \text { PENEGAKAN } & \text { HUKUM } \\ \text { YANG } & \text { BERKEADILAN } & \text { DI }\end{array}$


INDONESIA." Justicia Islamica 13, no. 2 (2016). http://jurnal.stainponorogo.ac.id/i ndex.php/justicia/article/view/58

5.

"Pedoman Matakuliah Pendidikan Kewarganegaraan (Pkn) Sebagai Mata Kuliah Wajib Umum (MKWU)." DIKTI-MKWU, 2014.

Prasetyo, Teguh. "Hukum Dan Sistem Hukum Berdasarkan Pancasila." Cetakan Pertama, Yogyakarta: Media Perkasa, 2013.

Rahmi. "Kontribusi Matematika Dalam Pembentukan Karakter Siswa." Jurnal Ekotrans 12 No. 1 (2013).

Saputra, Edi. "Eksistensi PKn Sebagai Pendidikan Nilai Dalam Membangun Karakter Bangsa." TINGKAP 8, no. 2 (2012): 145-158.

"Undang-Undang Republik Indonesia Nomor 20 Tahun 2003 Tentang Sistem Pendidikan Nasional Pasal 1 Ayat (1)," n.d. 
